\title{
Glyphosate-Resistant Common Ragweed Control in Corn with Postemergence Herbicides
}

\author{
Nader Soltani, Lynette R. Brown, Peter H. Sikkema \\ University of Guelph Ridgetown Campus, Ridgetown, Canada \\ Email: soltanin@uoguelph.ca
}

How to cite this paper: Soltani, N., Brown, L.R. and Sikkema, P.H. (2018) Glyphosate-Resistant Common Ragweed Control in Corn with Postemergence Herbicides. Agricultural Sciences, 9, 670-675. https://doi.org/10.4236/as.2018.96046

Received: May 9, 2018

Accepted: June 17, 2018

Published: June 20, 2018

Copyright $\odot 2018$ by authors and Scientific Research Publishing Inc. This work is licensed under the Creative Commons Attribution International License (CC BY 4.0).

http://creativecommons.org/licenses/by/4.0/

\section{(c) (i) Open Access}

\begin{abstract}
Four field trials were conducted on a farm infested with glyphosate-resistant (GR) common ragweed during 2016 and 2017 to evaluate various postemergence (POST) herbicides for the control of GR common ragweed in GR corn. Dicamba at 600 g.a.i. $\cdot a^{-1}$, dicamba/diflufenzopyr at 200 g.a.i.ha ${ }^{-1}$, dicamba/atrazine at 1500 g.a.i. ha ${ }^{-1}$, topramezone + atrazine at $12.5+500$ g.a.i.ha ${ }^{-1}$, bromoxynil + atrazine at $280+1500$ g.a.i.ha ${ }^{-1}$, glufosinate at 500 g.a.i.ha ${ }^{-1}$ and $2,4-\mathrm{D}$ ester at $560 \mathrm{~g}$.a.i. ha $^{-1}$ provided $58 \%$ to $85 \%$ control at $4 \mathrm{WAA}$ and $49 \%$ to $88 \%$ control at 8 WAA. Other herbicides evaluated controlled GR common ragweed $9 \%$ to $41 \%$. Common ragweed density was reduced $97 \%$, $95 \%, 95 \%$ and $87 \%$ and shoot dry weight was reduced $93 \%, 95 \%, 94 \%$ and $90 \%$ with bromoxynil + atrazine, dicamba, glufosinate and topramezone + atrazine applied POST in GR corn, respectively. Results show that dicamba, bromoxynil + atrazine, topramezone + atrazine and glufosinate applied POST are the most efficacious herbicides among the herbicides evaluated for the control of GR common ragweed in GR corn.
\end{abstract}

\section{Keywords}

Glyphosate-Resistance, Atrazine, Bromoxynil, Dicamba, Glufosinate, Topramezone, Injury, Yield

\section{Introduction}

The spread of glyphosate-resistant (GR) weeds in North America is threatening the ability of crop producers to sustain the use of glyphosate and glyphosate-resistant crop technology [1]. There are currently 41 glyphosate-resistant weed species around the world in 37 countries and 40 crops/non-crop fields [2]. In Canada, there are currently six known GR weed species and four of them have been documented in Ontario [1]. The first case of GR Ambrosia artemisiifolia 
was documented in Ontario in 2011 and subsequent studies have shown that many of these biotypes found are also resistant to the Group 2 (acetolactate synthase [ALS] inhibiting) herbicides [1].

Common ragweed is a broadleaf weed from the Asteraceae family with a prolonged emergence pattern which has the potential to produce as much as one billion pollen grains per plant [3]. The pollen grains can then be transported more than $200 \mathrm{~km}$ by the wind [3]. In Ontario, common ragweed is considered a noxious weed that is responsible for causing hay fever in humans and land owners are therefore required by law to eradicate common ragweed weeds on their land [4]. Common ragweed is a hard-to-control troublesome weed in Ontario. A recent opinion poll survey conducted among people involved in agriculture across Ontario ranked common ragweed as the third most troublesome weed in Ontario [5]. In Ontario, corn yield losses of $38 \%$ have been reported with $>32$ plants $\mathrm{m}^{2}$ of common ragweed [6]. Greater yield losses have been reported in soybean. Weaver [6] found as much as 70\% yield loss and Van Wely et al. [7] found as much as $73 \%$ yield loss when common ragweed was not controlled in soybean under Ontario environmental conditions.

There are several registered postemergence (POST) herbicides that can control common ragweed including glyphosate, 2,4-D ester, atrazine, dicamba, dicamba/diflufenzopyr, dicamba/atrazine, bromoxynil + atrazine, prosulfuron + dicamba, mesotrione + atrazine, topramezone + atrazine, tembotrione/thiencarbazone-methyl, glufosinate, and halosulfuron. However, there is little information on the efficacy of these herbicides to control GR common ragweed in GR corn under Ontario environmental conditions. This information is critical for corn growers to maximize control, minimize weed competition, and maximize corn yield and profitability as well as reducing loading of ineffective herbicides into the environment.

The objective of this research is to evaluate currently registered postemergence corn herbicides at the highest labelled rate for the control of GR common ragweed in GR corn under Ontario environmental conditions.

\section{Materials and Methods}

The study consisted of four field trials conducted over a two-year period (2016, 2017). Field experiments were established as a randomized complete block design (RCBD) with 4 replications in a field infested with GR common ragweed near Tecumseh, Ontario. Treatments are listed in Table 1. Each plot included 4 rows of glyphosate-resistant corn ( $0.75 \mathrm{~m}$ apart and $8 \mathrm{~m}$ long) seeded $5 \mathrm{~cm}$ deep at the rate of 75,000 seeds ha ${ }^{-1}$ in May of each year.

Herbicide treatments were applied with a $\mathrm{CO}^{2-}$ pressurized back-pack sprayer calibrated to deliver $200 \mathrm{~L} \cdot \mathrm{ha}^{-1}$ of water at $200 \mathrm{kPa}$ using a boom with four Hypro ULD120-02 nozzle tips spaced $0.5 \mathrm{~m}$ apart. GR common ragweed was approximately $10 \mathrm{~cm}$ in height at the time of herbicide application. 
Table 1. Percent control 4 and 8 WAA, density and dry weight 4 WAA for glyphosate-resistant (GR) common ragweed in glyphosate-resistant corn treated with glyphosate plus various POST herbicides in 2016 and $2017 .^{\text {a }}$

\begin{tabular}{|c|c|c|c|c|c|}
\hline \multirow{2}{*}{ Treatment $^{\mathrm{b}}$} & \multirow{2}{*}{$\begin{array}{c}\text { Rate } \\
\left(\mathrm{g} \cdot \mathrm{ai} \cdot \mathrm{ha}^{-1}\right)\end{array}$} & \multicolumn{2}{|c|}{$\begin{array}{l}\text { GR Common Ragweed } \\
\text { Visible Control (\%) }\end{array}$} & \multirow{2}{*}{$\begin{array}{l}\text { Density } \\
\left(\# \mathrm{~m}^{-2}\right)\end{array}$} & \multirow{2}{*}{$\begin{array}{c}\text { Dry } \\
\text { Weight } \\
\left(\mathrm{g} \cdot \mathrm{m}^{-2}\right)\end{array}$} \\
\hline & & 4 WAA & 8 WAA & & \\
\hline Weedy control & & $0 \mathrm{~g}$ & $0 \mathrm{e}$ & $202 \mathrm{e}$ & $107 \mathrm{e}$ \\
\hline Weed-free control & & 100 & 100 & $0 \mathrm{a}$ & $0 \mathrm{a}$ \\
\hline Glyphosate & 900 & $9 \mathrm{fg}$ & 10 de & $171 \mathrm{de}$ & $85 \mathrm{e}$ \\
\hline 2,4 -D ester & 560 & 58 abcde & $49 \mathrm{abcd}$ & $58 \mathrm{cde}$ & 29 bcde \\
\hline Atrazine & 1000 & $22 \mathrm{ef}$ & $19 \mathrm{~d}$ & $137 \mathrm{de}$ & $81 \mathrm{e}$ \\
\hline Dicamba & 600 & $85 \mathrm{a}$ & $88 \mathrm{a}$ & $11 \mathrm{bc}$ & $5 \mathrm{~b}$ \\
\hline Dicamba/diflufenzopyr ${ }^{c}$ & 200 & $77 \mathrm{ab}$ & $86 \mathrm{a}$ & 54 cde & 23 bcde \\
\hline Dicamba/atrazine & 1500 & $77 \mathrm{ab}$ & $83 \mathrm{a}$ & 42 bcde & 19 bcde \\
\hline Bromoxynil + atrazine & $280+1500$ & $75 \mathrm{abc}$ & $62 \mathrm{abc}$ & $7 b$ & $7 \mathrm{bc}$ \\
\hline Prosulfuron + dicamba $^{\mathrm{d}}$ & $10+140$ & $37 \mathrm{def}$ & $37 \mathrm{bcd}$ & $112 \mathrm{de}$ & 63 de \\
\hline Mesotrione + atrazine ${ }^{\mathrm{d}}$ & $100+280$ & $38 \mathrm{cdef}$ & $33 \mathrm{bcd}$ & $117 \mathrm{de}$ & $49 \mathrm{cde}$ \\
\hline Topramezone + atrazine & $12.5+500$ & $76 \mathrm{ab}$ & $68 \mathrm{ab}$ & $26 \mathrm{bcd}$ & $11 \mathrm{bcd}$ \\
\hline Tembotrione/thiencarbazone-methyl & 45 & 41 bcdef & $36 \mathrm{bcd}$ & $110 \mathrm{de}$ & $50 \mathrm{cde}$ \\
\hline Glufosinate & 500 & $71 \mathrm{abcd}$ & $69 \mathrm{ab}$ & $10 \mathrm{bc}$ & $6 \mathrm{~b}$ \\
\hline Halosulfuron $^{c}$ & 70 & $26 \mathrm{ef}$ & $24 \mathrm{~cd}$ & $122 \mathrm{de}$ & $75 \mathrm{de}$ \\
\hline
\end{tabular}

aAbbreviations: POST, postemergence; WAA, weeks after herbicide application. Means followed by the same letter within a column are not significantly different according to Tukey-Kramer multiple range test at $\mathrm{P}<0.05$. ${ }^{\mathrm{b}}$ All treatments included glyphosate (900 g ae/ha). ${ }^{\mathrm{C}}$ Includes Agral 90 (0.25\% v/v). ${ }^{\mathrm{d}}$ Includes Agral $90(0.20 \% \mathrm{v} / \mathrm{v})$.

Crop injury was estimated visually 2 and 4 weeks after treatment application (WAA) on a scale of 0 to 100 with zero representing no injury and 100 representing complete plant death. Additionally, GR common ragweed control was visually estimated at 4 and 8 WAA on a scale of 0 (no weed control) to 100 (complete weed control). Density and shoot dry weight (biomass) of GR common ragweed were determined at 4 WAA by counting the number of GR common ragweed contained in two randomly-placed $0.5 \mathrm{~m}^{2}$ quadrats per plot. GR common ragweed was cut at the soil surface, put into paper bags, dried at $60^{\circ} \mathrm{C}$ to constant moisture, and the shoot biomass recorded. Yield was implemented by hand harvesting two middle rows of corn in the weedy (no weed control measures were implemented) and weed-free control (maintained free of weed the entire season) plots.

Data analysis was carried out using the GLIMMIX procedure in SAS. The Laplace method was used for estimation due to the advantages it provides over the pseudo-likelihood approach: fit statistics based on information criteria are meaningful and estimates have less bias for smaller sample sizes [8]. Herbicide 
treatments were considered fixed effects while environment (year and location), replication within environment and the environment by treatment interaction were considered random effects and variances were partitioned accordingly. The F-test and the likelihood ratio tests were used to test the significance of fixed effects and random effects, respectively [9]. The AICC and residual analysis were used to assess different models and distributions. Once a final model was confirmed, least square means (LSMEANS) were calculated and Tukey's adjustment was applied to pairwise comparisons to determine differences among treatment means ( $\mathrm{p}<0.05)$. Percent control of GR common ragweed at 4 and 8 WAA was analyzed using a Gaussian distribution; GR common ragweed density and biomass data were best described using a lognormal distribution. The default identity link function was used in both cases. In all cases where a treatment was assigned a value of 0 (weedy control for percent control, weed-free control for density and biomass) or 100 (weed-free control for percent control), it was excluded from the analysis because the data for these treatments had zero variance. However, the LSMEANS output provides information on whether each treatment least square mean differs from zero. This information was used to identify differences between the treatments included in the analysis and the excluded control treatments assigned a value of zero. Treatment means were back-transformed for presentation in Table 1 [10].

\section{Results and Discussion}

Corn injury at 2 and 4 WAA was low and transient with all treatments (data not shown).

The corn yield averaged $2.25 \mathrm{t} \cdot \mathrm{ha}^{-1}$ in weedy plots and $10.43 \mathrm{t} \cdot \mathrm{ha}^{-1}$ in weed-free plots, representing a $78 \%$ corn yield reduction due to GR common ragweed interference.

Among herbicides evaluated, glyphosate at 900 g.a.e. ha $^{-1}$, atrazine at 1000 g.a.i.ha ${ }^{-1}$, prosulfuron + dicamba at $10+140 \mathrm{~g} \cdot$ a.i. $\cdot \mathrm{ha}^{-1}$, mesotrione + atrazine at $100+280$ g.a.i.ha ${ }^{-1}$, tembotrione/thiencarbazone-methyl at 45 g.a.i.ha ${ }^{-1}$, and halosulfuron at $70 \mathrm{~g} \cdot$ a.i. $\cdot \mathrm{ha}^{-1}$ applied POST provided only $9 \%$ to $41 \%$ control of GR common ragweed at $4 \mathrm{WAA}$ and $10 \%$ to $37 \%$ control of GR common ragweed at 8 WAA (Table 1). Dicamba at 600 g.a.i. ha ${ }^{-1}$, dicamba/diflufenzopyr at $200 \mathrm{~g} \cdot$ a.i. $\cdot \mathrm{ha}^{-1}$, dicamba/atrazine at $1500 \mathrm{~g} \cdot$ a.i. $\cdot \mathrm{ha}^{-1}$, topramezone + atrazine at $12.5+500$ g.a.i.ha ${ }^{-1}$, bromoxynil + atrazine at $280+1500$ g.a.i.ha ${ }^{-1}$, glufosinate at 500 g.a.i.ha ${ }^{-1}$ and 2,4-D ester at 560 g.a.i. ha ${ }^{-1}$ were the best treatments among the herbicides evaluated controlling GR common ragweed $58 \%$ to $85 \%$ at 4 WAA and $49 \%$ to $88 \%$ at 8 WAA.

In studies conducted in Nebraska under greenhouse conditions, Ganie and Jhala [11] reported excellent (87\% - 99\%) control of GR common ragweed with 2,4-D, bromoxynil, dicamba/diflufenzopyr, glufosinate, halosulfuron plus dicamba, mesotrione + atrazine and tembotrione applied POST at 3 WAA. In 
contrast, other corn herbicides such as dicamba, halosulfuron, primisulfuron, carfentrazone, and thiencarbazone-methyl + tembotrione applied POST provided only $15 \%$ to $68 \%$ control of GR common ragweed [11]. Zollinger and Ries [12] reported that topramazone and tembotrione applied POST controlled glyphosate-susceptible (GS) common ragweed $97 \%$ and $94 \%$, respectively. However, mesotrione applied POST provided only $52 \%$ control of GS common ragweed [12]. In contrast, Whaley et al. [13] found that mesotrione + atrazine applied POST provided less than adequate control of GS common ragweed in corn.

Bromoxynil + atrazine, dicamba, glufosinate and topramezone + atrazine applied POST reduced density of GR common ragweed $97 \%, 95 \%, 95 \%$ and $87 \%$, respectively. However, glyphosate, 2,4-D ester, atrazine, dicamba/diflufenzopyr, dicamba/atrazine, prosulfuron + dicamba, mesotrione + atrazine, tembotrione/thiencarbazone-methyl and halosulfuron applied POST did not cause any signification reduction in density of GR common ragweed.

Common ragweed biomass reduction with herbicides evaluated showed the same trend as the density evaluations (Table 1). Dicamba, glufosinate, bromoxynil + atrazine and topramezone + atrazine applied POST reduced shoot dry weight of GR common ragweed $95 \%, 94 \%, 93 \%$ and $90 \%$, respectively. However, GR common ragweed shoot dry weight was not significantly affected with the other POST herbicides evaluated. In other studies, Ganie and Jhala [11] reported $80 \%$ to $91 \%$ GR common ragweed shoot dry weight reduction with corn herbicides such as glufosinate, bromoxynil, dicamba/diflufenzopyr, tembotrione and mesotrione + atrazine, applied POST. In contrast other corn herbicides such as dicamba, halosulfuron, primisulfuron, mesotrione, topramezone, carfentrazone, halosulfuron + dicamba and thiencarbazone-methyl + tembotrione have been shown to reduce GR common ragweed only $34 \%$ to $79 \%$ [11].

\section{Conclusions}

Dicamba, bromoxynil+atrazine, topramezone+atrazine and glufosinate applied POST were the best treatments among herbicides evaluated for the control of GR common ragweed in GR corn. Topramezone was more efficacious than other HPPD inhibitor herbicides such as mesotrione and tembotrione in controlling GR common ragweed. Inadequate GR common ragweed control in this study can be attributed to the fact that GR common ragweed biotypes at this site have been shown to be resistant to both glyphosate and Group 2 (ALS inhibiting) herbicides [1].

This study concludes that among herbicides evaluated, dicamba at 600 g.a.i.ha ${ }^{-1}$, bromoxynil + atrazine at $280+1500 \mathrm{~g} \cdot$ a.i. $\cdot \mathrm{ha}^{-1}$, topramezone + atrazine at $12.5+$ 500 g.a.i. ha $^{-1}$ and glufosinate at 500 g.a.i.ha ${ }^{-1}$ applied POST are the most efficacious herbicides for controlling GR common ragweed in GR corn. Inadequate control of GR common ragweed observed with many of the registered POST herbicides evaluated in this study emphasizes the need for more research to develop new integrated weed management programs for the control of this prob- 
lematic weed in Ontario.

\section{References}

[1] Heap, I. (2017) The International Survey of Herbicide Resistant Weeds. http://www.weedscience.org

[2] Heap, I. and Duke, S.O. (2017) Overview of Glyphosate-Resistant Weeds Worldwide. Pest Management Science. https://doi.org/10.1002/ps.4760

[3] Mitich, L.W. (1996) Ragweeds (Ambrosia spp.) The Hay Fever Weeds. Intriguing World of Weeds. http://wssa.net/weed/intriguing-world-of-weeds/\#x

[4] Cowbrough, M.J. (2006) Noxious Weed Profile-Ragweed spp. Ontario Ministry of Agriculture Food and Rural Affairs. http://www.omafra.gov.on.ca/english/crops/facts/info_ragweed.htm

[5] Bilyea, D. (2016) Ontario Weed Survey. University of Guelph Ridgetown Campus, Ridgetown.

[6] Weaver, S.E. (2001) Impact of Lamb's-Quarters, Common Ragweed and Green Foxtail on Yield of Corn and Soybean in Ontario. Canadian Journal of Plant Science, 81, 821-828. https://doi.org/10.4141/P01-057

[7] Van Wely, A.C., Soltani, N., Robinson, D.E., Hooker, D.C., Lawton, M.B. and Sikkema, P.H. (2014) Control of Glyphosate and Acetolactate Synthase Resistant Common Ragweed (Ambrosia artemisiifolia L.) in Soybean (Glycine max L.) with Preplant Herbicides. American Journal of Plant Sciences, 5, 3934-3942. https://doi.org/10.4236/ajps.2014.526412

[8] Gbur, E.E., Stroup, W.W., McCarter, K.S., Durham, S., Young, L.J., Christman, M., West, M. and Kramer, M. (2012) Analysis of Generalized Linear Mixed Models in the Agricultural and Natural Resources Sciences. American Society of Agronomy, Crop Science Society of America, and Soil Science Society of America, Madison, Wisconsin.

[9] Yang, R.-C. (2010) Towards Understanding and Use of Mixed-Model Analysis of Agricultural Experiments. Canadian Journal of Plant Science, 90, 605-627. https://doi.org/10.4141/CJPS10049

[10] Rothery, P. (1988) A Cautionary Note on Data Transformation: Bias in Back-Transformed Means. Bird Study, 35, 219-221. https://doi.org/10.1080/00063658809476992

[11] Ganie, Z.A. and Jhala, A.J. (2017) Confirmation of Glyphosate-Resistant Common Ragweed (Ambrosia artemisiifolia) in Nebraska and Response to POST Corn and Soybean Herbicides. Weed Technology, 31, 225-237. https://doi.org/10.1017/wet.2016.26

[12] Zollinger, R. and Ries, J.L. (2006) Comparing Mesotrione, Tembotrione, and Topramezone. Proceedings of 61 st Annual Meeting of the North Central Weed Science Society, Milwaukee, WI, North Central Weed Science Society, p. 114.

[13] Whaley, C.M., Armel, G.R., Wilson, H.P. and Hines, T.E. (2006) Comparison of Mesotrione Combinations with Standard Weed Control Programs in Corn. Weed Technology, 20, 605-611. https://doi.org/10.1614/WT-05-042R1.1 